\section{The Italian Chemical Congress at Palermo and the Cannizzaro Centenary.}

THE second Italian National Congress of pure and applied chemistry was held at Palermo, Sicily, on May 22-June I, simultaneously with the centenary celebrations of the Sicilian chemist Stanislao Cannizzaro, who was born in Palermo in 1826 . A monument was unveiled to his memory, and the Italian Chemical Society is publishing a book describing the main features of his life and work. Sir William Tilden, who delivered the Cannizzaro Memorial Lecture to the Chemical Society, summed up Cannizzaro's contributions to chemistry very broadly under the two following heads: "First, he laid down for all time the two principal methods by which atomic weights are determined, the one by reference to the molecular weights derived from an application of Avogadro's rule, and the other by an adoption of the principle discovered by Dulong and Petit as to the general relation of atomic weight to specific heat among the solid elements, and he showed that these two methods when applicable to the same case lead to the same results. Secondly, he placed inorganic chemistry in a new light by applying to inorganic compounds the same principles which had been applied to organic compounds, and thus finally disposed of the superstition which had hovered so long in the minds of chemists that organic chemistry was subject to laws different from those prevailing among mineral substances."

No better place could have been found than Palermo for the centenary celebrations. Not only was Cannizzaro born there, but also for ten years he held the chair of organic and inorganic chemistry at that University, refusing chairs at both Pisa and Naples in order to take it. He only left it to take the highest post in chemistry that Italy could bestow, the chair at Rome. During the Sicilian revolution in 1847 he left his studies under Piria to serve as an artillery officer in the Sicilian army, and handled his battery so well at Messina that he was sent to Taormina to oppose the Neapolitan troops. The final defeat of the Sicilian troops in 1849 made him a fugitive, and he finally made his way to Chevreul's laboratory in Paris, where he stayed until recalled to Italy in I $85 \mathrm{I}$ as professor at the National School at Alessandria, going four years later to Genoa, whence he published in 1858 his famous "Sunto di un Corso di Filosofia Chimica." In I860 he again took arms, this time under Garibaldi, but without seeing any active warfare. From I86r until r87I he held the chair at Palermo, and from there he went to Rome, being at the same time made a Senator of the kingdom. From then until his death, in rgro, his life was full and varied, and honours, both civil and scientific, were showered on him.

Besides the reading of numerous papers in various branches of chemistry, an interesting programme of sight-seeing in Sicily had been arranged for those who attended the Congress, and a wide field of historical and scientific interest was covered, amid some of the most magnificent scenery of southern Europe. The itinerary included a visit to Mondello, near Palermo, to inspect the works of the Societa Gen. Elettrica della Sicilia on May 25; to the Arenella Chemical Works on May 26; to the sulphur mines of Cozzi Disi, near Girgenti, and the Campfranco works of the Montecatini firm on May 28; to the asphalt deposits of Ragusa on May 29; to the Magnisi salt mines on May 30 ; to the sulphur mines and other places of interest near Catania-including Mt. Etna-on May 3I; and finally to Messina on June $I$.

NO. 2954, VOL. I I 7]

\section{University and Educational Intelligence.}

BIRMingham.- The following gifts have recently been announced : $50 l$. towards the expenses of the new Fuel Treatment Laboratory, by the Bromford Tube Co., Ltd. ; mounted illustrations for use in the Botanical Department, by Mrs. Wilson King; pair of telephones, shown at the Paris Exhibition in 1878 , by Mr. J. C. Vaudrey; two alternators, for use in the Electrical Engineering Laboratory, by Mr. W. F. Higgs.

CAmbridge.-The late Dr. J. E. Bles has left to the University an immediate gift of his scientific apparatus and books and the contents of his private library and (subject to his wife's life interest) the entire residue of his estate. The latter benefaction, is expressly for the purpose of founding a professorship, preferably in animal embryology.

A readership in ethnology is being established, the present post, a personal appointment for Dr. A. C. Haddon, terminating on his retirement at the end of the present term.

LEEDs.-Applications are invited, until June I9, for the open fellowship, value $200 l$., of the Institution of Gas Engineers for the prosecution of post-graduate research in gas chemistry. Particulars are obtainable from the Registrar of the University.

Dr. E. A. Owen, head of the Radiology Division of the National Physical Laboratory, Teddington, has been appointed to the chair of physics at the University College of North Wales, Bangor.

Leplay House August Vacation Courses include this year visits to Dinant and the valley of the Meuse; Rochefort and the Belgian Ardennes; Irish Lake District; and Bagnères-de-Bigorre, in the High Pyrenees. These visits are open to all students and others interested in the study of geography, geology, plant life, history, and sociology. Particulars can be obtained from Miss Margaret E. Tatton, Leplay House, 65 Belgrave Road, Westminster, S.W.I.

THE annual report on the work of the University of London presented on May 12 by the Principal Officer, Sir Cooper Perry, who is about to retire, shows a slight decrease, from 7603 to 7577 , in the total number of admissions and an increase from 31,623 to 32,353 in the number of candidates for all examinations. Of 3819 candidates for degrees, $230 \mathrm{I}$ were internal and $15 \mathrm{x} 8$ were external students; the number of internal students increased from 9002 to 9323 . Specially noteworthy among the private benefactions mentioned in the report is the gift of $20,000 l$. by Sir Daniel Stevenson for the establishment of a part-time chair of international history and for the development of a department dealing with that subject. Other private benefactions to the University amounted to about $55,000 l$. and the London School of Economics received more than $30,000 l$. from the Laura Spelman Rockefeller trustees. The progress of the movement for broadening the bases of university education is exemplified by the new regulations adding music and law as optional subjects to various examinations. The holiday course for foreigners held last summer attracted more applications for admission than any of its seventeen predecessors, and more than 200 had to be refused, which seems a pity. Those admitted numbered 256 , representing 22 nationalities. The courses in journalism are increasingly sought after; the number of students increased from 53 in $1924-25$ to 74 in $1925^{-26}$. The scheme of advisory service for external students introduced experimentally last year proved effective. 